\title{
GOOD INTENTIONS ARE NOT ENOUGH
}

\section{Kerstin Cassel}

Anders Gustafsson and Håkan Karlsson's paper raises a question which is of utmost importance for those engaged in archaeology and cultural heritage. There is no doubt that it is a question we all have to take into consideration, regardless of whether we consider archaeology as politics or not. And since I believe that there are few who want to be embraced to death by the Sweden Democrats (SD, Sw. Sverigedemokraterna) or other movements of that kind, there is hopefully a good opportunity for a lively discussion of the issue.

However, I am not fully convinced by the authors' conclusion, namely that it is the research councils and foundations that are the key to the problem. I do not intend to make a secret of the fact that I am partial in this case, since I am a member of one of the Swedish Research Council's evaluation panels and therefore one of the persons "who hold the positions of power concerning research resources". There is probably no need to say that I do not recognize myself in Gustafsson and Karlsson's description of a conservative and traditional archaeologist who avoids the political dimensions of archaeology. However, I find the question of the exploitation of the cultural heritage in a xenophobic direction too important to be restricted to an internal discussion, as I think there are additional underlying causes for our inability to handle the problem.

Gustafsson and Karlsson argue that it is the traditional theoretical focus on empiricism and cultural history that has opened the door for SD's exploitation of the cultural heritage, and they mention especially the project Agenda Cultural Heritage as one of the forces against this misuse. Maybe I think the division into a traditional/empirical research 
on the one hand and a research that has an awareness of the political dimensions on the other is a bit simplistic, but this is not my principal objection here. Equally important as the theoretical standpoints is how research projects, methods and results are formulated and put into words. We all have to be careful so that we do not use the same language as the xenophobic movement when we discuss the question of cultural heritage. With the help of two examples I will try to show what I regard as problems in communicating projects and results - problems that open up for misunderstanding and misuse.

One of the good examples put forward by Gustafsson and Karlsson is the National Heritage Board and the project Agenda Cultural Heritage. My argumentation here should not be understood as an accusation that those who were involved in the project did not do a good job or that they had a xenophobic agenda. Instead, I would like to attend to the fact that also well-intended aims can be phrased and formulated in a problematic way.

As Gustafsson and Karlsson point out, the project Agenda Cultural Heritage caused a lot of discussion. But the critical voices did not only come from the "defenders of the antiquarian sector's traditional aims and methods". In 2005 Åsa Wall published an article in Fornvännen titled "Agenda Cultural Heritage: Important Aims but Questionable Starting Points" (Sw. Agenda kulturarv: viktiga målsättningar men diskutabla utgångspunkter). The dilemma she focused on was the fact that those who argued in favour of Agenda Cultural Heritage sometimes expressed themselves in a problematic way. For example, in an interview in the newspaper Svenska Dagbladet in 2004, the director of the National Heritage Board talked about "we" and "them" as if there were a natural clash of interest between two different groups. Inger Liliequist was worried that the citizens who have "their roots in other countries and cultures do not see our cultural heritage in the same way as we do" (my italics and translation), and that the cultural heritage that is highly valued by us means nothing to them. In a report from the National Heritage Board a similar doubt is expressed, and it is said that the cultural heritage sector has to "recognize and confirm that immigrants as well have a history and a cultural heritage" (Riksantikvarieämbetet 2002:I I, my translation). Contrary to the ambition, which is to create participation, one falls into an argumentation that pits groups against each other. The society is divided into two groups: "we" who are Swedish (and who understand the Swedish cultural heritage) and "them" who need our help to understand it (or to find their own cultural heritage). To discern one group (the immigrants) as a problem, no matter if it is a question concerning school or the labour market or the cultural heritage, is un- 
fortunately a way of both maintaining and creating discriminatory attitudes, and it is an established description of Sweden today. However, irrespective of the intentions, the argumentation falls into the same jargon as the one that claims that immigrants from foreign cultures are so different from us that they could never be part of the Swedish society.

And I am not sure if this anxiety about the cultural heritage (an anxiety which seems to think of the cultural heritage as ethnical) is the right way to approach the issue. Let us, for instance, consider the artefacts from ancient times that are a large part of the Swedish cultural heritage. They are Swedish in the sense that they have been found on Swedish land, and not because they are supposed to constitute something traditionally Swedish. On the contrary, they are treated the same way irrespective of their origin. The thousands of Islamic coins from the late Iron Age belong to the Swedish cultural heritage, as do the bronzes from Hungary and the silk from Asia. Am I as a Swede supposed to feel more closely related to these artefacts than an immigrant would? Why does the cultural heritage sector assume that people from foreign countries cannot understand the cultural value of such objects? I welcome the debate about what should constitute the cultural heritage in the future and how archaeologists can tell people about it, but I object to the notion that it should be done because Sweden is supposed to be a more multicultural society today. This kind of argumentation is conducted in a framework formulated by SD and similar movements. For this reason it is not enough to have good intentions, as the formulation says something different.

My second example shows how the media and reports of research results describe culture as something biological and inherent in our genes and thus immutable. Parts of the archaeological cultural heritage consist of ancient bones, bones that are often studied by natural science. One might think that the way science handled questions on race and culture during the first half of the 2 oth century should have spawned some caution, but this is not always the case. In the morning paper Dagens $N y$ heter in November 2010 we could read an article about the introduction of agriculture in Sweden. The text reports that the question of economic strategies could be explained with the help of DNA. Analysis of ancient bones is said to indicate that a superior people with "agriculture DNA" superseded a group with "hunter's DNA". The fact that the researcher Anders Götherström of Uppsala University actually assumes that a manner of living is linked to a specific DNA (in this case the mobile hunter's), is underlined when he states that the research group was surprised to find that the "hunter's DNA" did not resemble the modern Saami DNA. Surprised - for what reason? This is one example of the fact that DNA has 
replaced the forbidden words "race" and "blood", but that the story of well-defined people whose cultures are determined by biology remains the same as it was a century ago. Furthermore, in the introduction to the article we are told that: "About six thousand years ago the first farmers immigrated to the area that is now Sweden. The hunters that lived in the area were pushed away. Today's Swedes originate from these farmers rather than from the hunters (Bojs 20Io, my translation). One of the questions is which Swedes the journalist is referring to. She seems to have forgotten the thousands of years of immigration since the introduction of agriculture. In the last 50 years alone, almost two million people have migrated to Sweden. Hopefully it is only naivety and carelessness with words that lie behind these formulations, but irrespective of this, such texts mediate a problematic image of the cultural heritage.

I am aware that these examples are disparate, but my point is to show that the way we express ourselves can result in readings quite contrary to what was intended. This is true no matter if we use the phrase "today's Swedes" and thereby exclude a great part of the Swedish population, or if we (despite good intentions) single out a group that needs a special kind of treatment. Consequently, I fully agree with Gustafsson and Karlsson that we have to be conscious of the political dimensions in archaeology and in the management of the cultural heritage.

I think that one way is to be careful with words and to recognize that our society's structural problems also permeate our way of describing the world. This does not necessarily have to do with the kind of archaeology being conducted, but more with how it is formulated and narrated. And I am sure that the archaeological cultural heritage has a lot of stories worth telling - stories that do not necessarily exclude some members of society.

Kerstin Cassel Södertörn University I4 I 89 Huddinge, Sweden

\section{REFERENCES}

Bojs, K. 20IO. Nordens bönder kom från Turkiet. Dagens Nyheter. 20I0-I I-2 I. Pp. 30-3I.

Riksantikvarieämbetet. 2002. Det dynamiska kulturarvet. Omvärldsanalys för kulturmiljöområdet 2002. http://www.raa.se

Svenska Dagbladet. 2004. Ny väg för historiskt bevarande. 2004-04-24.

Wall, A. 2005 . Agenda kulturarv: viktiga målsättningar men diskutabla utgångspunkter. Fornvännen. Pp.43-45. 